\title{
Service Convenience and Customer Loyalty: Findings from Convenience Stores in Guangzhou
}

\author{
Hong Jin, Shijie Wang, Feng Yang, Huiming Xu \\ Business School \\ Jiangxi Normal University \\ Nanchang, China
}

\begin{abstract}
This paper aims to study the multiple relations between service convenience and customer loyalty with SPSS21.0. software. Thus, a variable, multi-dimensional and nonlinear hypothesized model is developed to explore how service convenience influences customer loyalty. To obtain practical implications, different research methods used in this research are questionnaire analysis, the transformation of theoretical framework, and linear regression analysis: the linear regression of service convenience on customer satisfaction, service convenience on customer loyalty, and customer satisfaction on customer loyalty. Results reveal that service convenience has positive impacts on both customer satisfaction and customer loyalty, which implies that chain store managers should attach importance to the improvement of service convenience.
\end{abstract}

Keywords-convenience store; service convenience; customer satisfaction; customer loyalty

\section{INTRODUCTION}

With the rapid development of China's economy, the improvement of people's income level, the change of consumption habits and increasingly fierce competition among enterprises, consumer price sensitivity is gradually decreasing in the daily consumption of commodities. Compared with the price, people pay more attention to time cost when purchasing, which indicates the increasing demand for convenience. According to Nielsen Research, the rate of queues in retail stores reaches $43 \%$, with $28 \%$ saying that they would choose another store because of the long waiting time in the queues and 66\% leaving directly [7]. Queuing has become a major problem faced by retail enterprises and it reflects consumers' urgent demand for convenience.

Therefore, in the era of service economy, all the brand is searching for the secret of maintaining their competitiveness. How to improve service quality and cultivate customer loyalty has become the primary problem that enterprises need to fix up, especially in the convenience store industry where product types and management models are both particularly similar. Therefore, it is a vital issue for the managers of convenience stores to figure out how to enhance customer perception of service convenience, how to improve customer satisfaction and how to build customer loyalty. And there are a lot of theories mainly focus on how to improve customer satisfaction and what factors influence customer loyalty.

\section{THEORETICAL BACKGROUND AND HYPOTHESES DEVELOPMENT}

\section{A. Research on convenience store}

Convenience Store is a new type of retail format that not only characterized by convenience but also adopts the supermarket managing model. Born in the United States, it perfectly developed in Japan and was introduced into China at the end of the 20th century, still making continuous progress up to now. The convenience store has three typical attributes: convenience, stability as well as low-risk, modernization and informatization. [10].

\section{B. Research on service convenience}

American marketing scholar, Copeland (1923) firstly introduced the concept of convenience into the classification of commercial wares and elaborated what the convenience goods were [2]. Later academics regarded the convenience as the characteristic of commodities which were used to cater for the consumer's need. Carmon (1995) proposed an important standpoint that the consumer could perceive the waiting time in his research on psychological perceive study of service segment [4]. His conclusion indicated that reasonably segmenting the service could effectively reduce the waiting time and improve consumer's perception of the service convenience. Durrande-Moreau (1999) presented that the perception of individual was different. Both objective waiting time and time that consumers perceived had different influences on the consumer cognition [5]. Based on the particularity of service, Berry (2002) presented a statement of the exact meaning of service convenience that consumers' perception of time and energy they expended were related to the process of purchasing or using one service or goods. And he deemed that service convenience includes decision convenience, access convenience, transaction convenience, benefit convenience, post-benefit convenience [1]

\section{Research on customer satisfaction}

Customer satisfaction was firstly proposed by Cardozo (1965) who used it in marketing and created the term of consumer satisfaction which means cunstomers' repeat buying or using same goods [3]. Westbrook (1980) indicated that consumer satisfaction was a personal favor which came from 
the subjective evaluations and various outcomes after purchasing the products [11]. Based on previous literature, this article found that consumer satisfaction chiefly consists of three factors: 1. Consumers' different responses to satisfaction; 2. Consumer satisfaction was produced in the process of products selecting, purchasing and consuming. 3 . The time that consumers felt the content was distinctive but the duration was often limited. Thus, this article argues that the responsiveness of services, that is, serving customers in the most convenient way would have a positive impact on customer satisfaction. The authors hypothesize that:

H1: Service convenience has a positive impact on customer satisfaction.

\section{Research on customer loyalty}

Customer loyalty was primely used to evaluate consumer behavior. Jacoby and Chestnut (1978) viewed that consumer loyalty caused customers' repeat purchase of the same goods. However, it was limited by the environment of consumption, such as lacking brand pursuits and preferences. Therefore, it is unpersuasive to explain consumer loyalty merely relying on consumer behaviors [6]. In the research of service loyalty, consumer loyalty possessed multi-dimensions which consisted of behavioral loyalty, attitude loyalty and cognitive loyalty. Besides, consumer loyalty was affected by satisfaction, conversion costs and relationships. Chinese scholars Zhengfeng Wang and Yunhua Liu (2003) argued that consumer loyalty represented not only a psychological trend but also a behavioral trend [12]. In short, it combined psychological preferences with behaviors of repeat purchasing. So hypothesis 2 is postulated:

H2: Service convenience has a positive impact on customer consumer loyalty.

Jinglun Han (2001) concluded in his study that the level of customer satisfaction and the formation of customer loyalty were influenced by the quality of service [7]. The more sensitive consumers are to service quality, the more likely they will produce a satisfactory psychological attitude, which in turn will lead to customer loyalty. Juan Lu (2006) suggested that when service quality meets customer's expectations, thus the customer would produce a satisfactory psychological state, which would result in customer loyalty, vice versa [8]. Lianxiong Jiang and Taihong Lu (2006) found that customer satisfaction had a direct impact on customer loyalty in the study of customer value, customer satisfaction [9]. Therefore, hypothesis 3 is proposed:

H3: Customer satisfaction has a positive impact on customer consumer loyalty.

\section{METHODOLOGY}

\section{A. Questionnaire and measures}

The questionnaire was based on a former scale and certain concepts in the previous literature. All responses were recorded by means of an ordinal 5-point Likert scale which ranged from “ 1 " to " 5 ". A method of randomly distributing was applied in the questionnaire. In addition, the items of the questionnaire were perfected in two ways. Firstly, to improve the accuracy of the measurement, the article took actual consumption situation in Guangzhou into account. Secondly, to avoid potential misinterpretation by respondents, one professor and three managers from the realm of brand management were interviewed to assess the adequacy of the questions from the conceptual standpoint.

\section{B. Data and sample collection}

Data collection was conducted in Guangzhou in 2019, selecting particular customers who used to consume in several brand convenience stores like 7-11. Respondents answered several filtering questions to prove that they had engaged in the consumption of these brand stores. With this method, a sample of 170 customers whose ages were mostly in the range from 18 to 35 was obtained. And 55.9\% of respondents were male and $51.76 \%$ of them were college students.

\section{Abbreviations and Acronyms}

In this article, we use several abbreviations such as DC, AC, TC, BC, PC, CS, CL, SC to substitute for decision convenience, access convenience, transaction convenience, benefit convenience, post-benefit convenience, consumer satisfaction, consumer loyalty, service convenience.

\section{DATA ANALYSIS AND RESULTS}

\section{A. The hypothesized model}

Based on the literature the article mentioned, the authors established the hypothesized model in this study (Fig. 1)

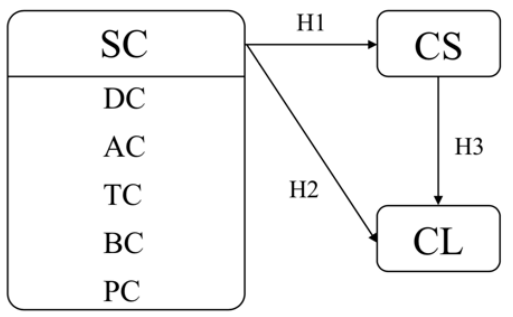

Fig. 1. The hypothesized model

\section{B. Reliability analysis}

Reliability analysis refers to the degree of consistency of results obtained by repeating measurements on the same object in the same way. The article calculates the mean and standard deviation of each indicator in the study by using SPSS21.0 software. TABLE I includes the Cronbach's Alpha coefficient of each items, which exceeds 0.8. It means that the scale reaches internal consistency and is highly reliable. 
TABLE I. RELIABILITY ANALYSIS RESULTS

\begin{tabular}{|c|c|c|}
\hline Variable & Item & Cronbach's Alpha coefficient \\
\hline DC & 4 & 0.929 \\
\hline AC & 3 & 0.881 \\
\hline BC & 5 & 0.943 \\
\hline TC & 3 & 0.894 \\
\hline PC & 3 & 0.888 \\
\hline CS & 3 & 0.894 \\
\hline CL & 3 & 0.891 \\
\hline
\end{tabular}

\section{Validity analysis}

The principal component analysis was performed on 22 indicators that measure service convenience by using the orthogonal rotation method. The KMO statistical value used to test the partial correlation between variables is 0.986, indicating that the correlation between the variables do not have much in common. The test results of Bartley's spherical hypothesis indicates that there is a strong correlation between the variables. Both of them demonstrate that the data is more suitable for exploratory factor analysis (EFA). The principal component analysis showed that the content of service convenience can extract 5 common factors, which are named as decision convenience, access convenience, transaction convenience, benefit convenience and post-benefit convenience. A total of $84.863 \%$ of the variance is explained.

\section{Correlation analysis}

Correlation analysis is used to study the relationships between quantitative data, using the Pearson correlation coefficient to represent the strength of the relationship. TABLE II shows the correlation between service convenience and consumer satisfaction or consumer loyalty. The correlation coefficients in TABLE III are all around 0.9 and have a significant level of 0.01. Therefore, there is a significant positive correlation between each factor in service convenience and customer satisfaction or customer loyalty.

TABLE II. PEARSON CORRELATION ANALYSIS RESULTS

\begin{tabular}{|c|l|l|}
\hline Factor & CA & CL \\
\hline DC & $0.914^{* *}$ & $0.918^{* *}$ \\
\hline AC & $0.907^{* *}$ & $0.904^{* *}$ \\
\hline BC & $0.917^{* *}$ & $0.925^{* *}$ \\
\hline TC & $0.902^{* *}$ & $0.903^{* *}$ \\
\hline PC & $0.904^{* *}$ & $0.892^{* *}$ \\
\hline
\end{tabular}

TABLE III explains the correlation between consumer satisfaction and consumer loyalty. The correlation coefficients in TABLE III is up to 0.894 and has a significant level of 0.01 , which indicates consumer satisfaction has a positive correlation with consumer loyalty.

TABLE III. PEARSON CORRELATION ANALYSIS RESULTS

\begin{tabular}{|c|c|}
\hline Factor & CL \\
\hline CS & $0.894^{* *}$ \\
\hline \multicolumn{2}{|c|}{ Note: $* \mathrm{p}<0.05^{* *} \mathrm{p}<0.01$} \\
\hline
\end{tabular}

\section{E. Regression analysis}

Regression analysis is used to study the relationship of influence, which is essentially the study of the influence of $\mathrm{X}$ on $\mathrm{Y}$ but the correlation does not necessarily lead to a regressive relationship. TABLE IV shows the regression relationship between service convenience and customer satisfaction. Results indicate that $\mathrm{R}^{2}$ equals 0.886 , which means all of factors can influence customer satisfaction. The authors find $\mathrm{F}$ equals 263.712 through F-test, namely, one of five factors can influence on customer satisfaction at least. Based on the results, the authors build up the equation:

- $C S=0.118 * D C+0.257 * A C+0.137 * B C+0.224 * T C+$ $0.245^{*} P C$

By comparing regression coefficients, authors find AC, TC and PC have a positive impact on customer satisfaction.

TABLE IV. REGRESSION ANALYSIS RESULTS

\begin{tabular}{|c|c|c|c|c|c|}
\hline & Beta & $\mathbf{t}$ & $\mathbf{p}$ & $\mathbf{R}^{2}$ & $\mathbf{F}$ \\
\hline DC & 0.118 & 1.247 & 0.214 & \multirow{5}{*}{0.886} & \multirow{5}{*}{$263.712\left(0.000^{* *}\right)$} \\
\hline AC & 0.257 & 3.419 & $0.001^{* *}$ & & \\
\hline AC & 0.137 & 1.404 & 0.162 & & \\
\hline TC & 0.224 & 3.065 & $0.003^{* *}$ & & \\
\hline $\mathrm{PC}$ & 0.245 & 3.328 & $0.001^{* *}$ & & \\
\hline
\end{tabular}

TABLE $\mathrm{V}$ shows the regression relationship between service convenience and customer loyalty. Results indicate that $\mathrm{R}^{2}$ equals 0.886, which means all of factors can be responsible for customer loyalty. The authors find F equals 262.902 through F-test, namely, factors can influence on customer loyalty. Based on the results, the authors build up the equation of this model :

- $C L=0.169 * D C+0.198 * A C+0.285 * B C+0.212 * T C+$ $0.111 * P T$.

By comparing regression coefficients, authors find AC, BC and TC have a positive impact on customer loyalty.

TABLE V. REGRESSION ANALYSIS RESULTS

\begin{tabular}{|c|c|c|c|c|c|}
\hline & Beta & $\mathrm{t}$ & $\mathrm{p}$ & $\mathrm{R}^{2}$ & F \\
\hline DC & 0.169 & 1.784 & 0.076 & \multirow{5}{*}{0.886} & \multirow{5}{*}{$262.902\left(0.000^{* *}\right)$} \\
\hline $\mathrm{AC}$ & 0.198 & 2.635 & $0.009^{* * *}$ & & \\
\hline $\mathrm{BC}$ & 0.285 & 2.923 & $0.004^{* *}$ & & \\
\hline TC & 0.212 & 2.902 & $0.004^{* *}$ & & \\
\hline PC & 0.111 & 1.508 & 0.134 & & \\
\hline
\end{tabular}

TABLE VI shows the regression relationship between customer satisfaction and customer loyalty. Results indicate that $\mathrm{R}^{2}$ equals 0.886 , which means customer satisfaction can be responsible for customer loyalty. Based on these results, the authors establish the equation:

\section{- $C L=0.894 * C S$}

The equation infers customer satisfaction can produce positive influences on customer loyalty. 
TABLE VI. REGRESSION ANALYSIS RESULTS

\begin{tabular}{|c|c|c|c|c|c|c|}
\hline & Beta & $\mathrm{t}$ & $\mathrm{p}$ & $\mathrm{R}^{2}$ & $\mathrm{R}^{2}$ & $\mathrm{~F}$ \\
\hline CS & 0.894 & 25.884 & $0.000^{* * *}$ & 0.8 & 0.798 & $669.965\left(0.000^{* *}\right)$ \\
\hline
\end{tabular}

\section{CONCLUSION}

\section{A. Theoretical contributions}

Above all, the article draws a conclusion that service convenience includes decision convenience, access convenience, transaction convenience, benefit convenience and post-benefit convenience. However, in the industry of convenience store, the real factors influencing customer satisfaction are access convenience, transaction convenience and post-benefit convenience, which illustrates customers have direct cognition of access, transaction and post-benefit. Namely, whether the location of the convenience store is easy to be found, whether the transaction process is fast enough and whether the after-sales service can respond in time affect customer satisfaction most.

And customer loyalty is directly affected by access convenience, benefit convenience and transaction convenience, which implies that only when managers enhance the cognition of customers' benefits, will they transform customer satisfaction into customer loyalty. In other words, it matches the business philosophy. In general, if some convenience stores mainly focus on selling beverage and fast-food, then it is not dispensable for managers to devote more energy in post-benefit convenience.

\section{B. Managerial implications}

The managerial implications of this article are as follows: enriching the function of convenience store; building up China's local chain convenience store brand and helping them strengthen customer loyalty.

Implications for managers from the article:

Firstly, they should pay more attention to the locationselecting of the store since it is a particularly vulnerable industry. For managers, if the store can't attract customers to purchasing, all the conditions they create will be in vain.

Besides, they should simplify the transaction process. It is possible that there will be numerous customers entering the store to purchase something they want at the same time, which would bring great pressure to the checkout counter. However, there are usually only one or two cashiers in the common convenience stores. Thus, the manager can adopt a way of selfcheckout. We are living in an internet world, so it is easy for us to purchase wares with our smartphones.

Last but not least, adding several extra services is necessary for convenience store, such as providing seats, heating foods, and so on. What's more, managers can prolong the opening hours.

\section{Limitations and future research}

The study has several limitations in sample sizes and industry applicability. Hence a further discussion on service convenience is still required in the future. Firstly, since there are few direct studies on the convenience of convenience store services in existing literature, the author is only allowed to make a quantitative table based on the concept statement of service convenience. Also, the number of factors included in the service convenience may be incomplete. Secondly, this study does not examine whether customer satisfaction plays an intermediary role in the study of the impact of service convenience on customer loyalty, and it lacks certain scientific rigor. Lastly, due to the geographic restrictions, only convenience stores and consumers in Guangzhou have been studied. What's more, it only adopts the online questionnaire method. Thus there may be some deviations from the actual situation in data collection, which has a certain influence on the research results and leads to some limitations.

\section{ACKNOWLEDGMENT}

This research was supported by National Natural Science Foundation of China(No.71562020), Thirteenth Five-Year Planning (2017) research project of Jiangxi Social Science (No.17GL05) and Jiangxi Universities Humanities and Social Sciences Research on Young Fund(GL17115).

\section{REFERENCES}

[1] Berry L L, Seiders K, Grewal D. Understanding service convenience[J]. Journal of Marketing, 2002, 66(3): 1-17.

[2] Copeland M T. Relation of consumers' buying habits to marketing methods[J]. Harvard Business Review, 1923, 1(2): 282-289.

[3] Cardozo R N. An experimental study of customer effort, expectation, and satisfaction[J]. Journal of Marketing Research, 1965, 2(3): 244-249.

[4] Carmon Z, Shanthikumar J G, Carmon T F. A psychological perspective on service segmentation models: The significance of accounting for consumers' perceptions of waiting and service[J]. Management Science, 1995, 41(11): 1806-1815.

[5] Durrande-Moreau A, Usunier J C. Time styles and the waiting experience: an exploratory study[J]. Journal of Service Research, 1999, 2(2): 173-186.

[6] Jacoby J, Chestnut R W, Fisher W A. A behavioral process approach to information acquisition in nondurable purchasing $[\mathrm{J}]$. Journal of Marketing Research, 1978, 15(4): 532-544.

[7] Jinglun Han. Study on the relationship between customer satisfaction and customer loyalty[J]. Nankai Business Review, 2001(06):8-10+29.

[8] Juan Lu et al. Service Loyal Drivers and Driving Mechanism-Based on Systematic Analysis of Relevant Theories and Empirical Research at Home and Abroad[J]. Management World, 2005(06):107-114+125.

[9] Lianxiong Jiang, Taihong Lu. Does image create value? The impact of service brand image on customer value, satisfaction and loyalty relationship[J]. Management world, 2006(04):106-114+129.

[10] Rongqing Li. Domestic convenience store development stage and classification research[N]. Sichuan Economic Daily, 2018-09-03(006).

[11] Westbrook $\mathrm{R}$ A. A rating scale for measuring product/service satisfaction[J]. Journal of Marketing, 1980, 44(4): 68-72.

[12] Zhengfeng Wang, Yunhua Liu.Western Customer Loyalty Research and Practice Enlightenment[J]. Contemporary Finance, 2003(02):89-92. 